\title{
SACRALISATION AND THE COLONIAL- INDIGENOUS ENCOUNTER IN SOUTHERN AFRICAN CHRISTIAN HISTORY: THE MEMORY AND LEGACY OF JOHANNES DU PLESSIS AS CASE STUDY
}

\section{Retief Müller}

University of Stellenbosch

retiefmuller@sun.ac.za

\section{ABSTRACT}

The role of the Dutch Reformed Church's mission policies in the development of apartheid ideology has in recent times come under increased scrutiny. In terms of the formulation of missionary theory within the DRC, the controversial figure of Johannes du Plessis played a significant role in the early twentieth century. In addition to his work as a mission theorist, Du Plessis was a biblical scholar at Stellenbosch University who was found guilty of heresy by his church body, despite having much support from the rank and file membership. This article asks questions regarding the ways in which his memory and legacy are often evaluated from the twin, yet opposing perspectives of sacralisation and vilification. It also considers the wider intellectual influences on Du Plessis such as the missiology of the German theologian, Gustav Warneck. Du Plessis's missionary theory helped to lay the groundwork for the later development of apartheid ideology, but perhaps in spite of himself, he also introduced a subverting discourse into Dutch Reformed theology. Some of the incidental consequences of this discourse, particularly in relation to the emerging theme of indigenous knowledge, are furthermore assessed here.

Keywords: Johannes du Plessis; Dutch Reformed Church; missionary theory; apartheid ideology; sacralisation; vilification; knowledge

\section{UNISA $\cong$}




\section{INTRODUCTION}

'Knowledge itself is power.' ${ }^{1}$ This phrase, translated here from the original Latin, first occurs in the writings of Sir Francis Bacon in 1597. After Bacon, a more simplified version has become a popular, often used quotation in the English language in the phrase 'knowledge is power'. It is, however, the original quotation by Bacon that I find revealing. To paraphrase it in the Kantian language that would make such an impact on Western thought from the following century onwards, it would seem that Bacon here conceives of knowledge as an end in itself, rather than a means to an end. When someone says that knowledge is power this can still imply an instrumental value for knowledge, but when this is further qualified to emphasise that knowledge itself is power then knowledge has intrinsic and unassailable value, much in the way that beauty also has intrinsic value. In other words it might be said to approach sacred status.

In this article I want to draw a connection between the concepts of sacred power and knowledge, both as found within the 'archive' of Christianity as an Empire religion, ${ }^{2}$ but also within indigenous knowledge systems. I argue the thesis that sacralisation ${ }^{3}$ has been a factor in both 1) Afrikaner reformed religiosity and 2) an integral component in indigenous knowledge systems in Southern Africa. The two types of religiosity have furthermore influenced one another in somewhat unexpected ways.

\section{SACRALISATION AS DEIFICATION}

There are several different ways in which one can discuss the sacralisation of power, but one way in which I want to refer to this has to do with a certain glorification, even deification of a person or an institution. Hero-worship might be a somewhat more direct, but also cruder way of describing my meaning in this respect. In itself sacralisation can of course be defined in various ways, both positively and negatively. The same could perhaps be posited regarding deification. From a Muslim point of view, the Church's so-called 'deification' of Jesus has been one of the main stumbling blocks in the history of Christian-Muslim relations. However, if one looks beyond obvious examples such as this one, I would suggest that it is perhaps the

1 Francis Bacon, 'Meditationes Sacrae,' Wikisource, https://en.wikisource.org/wiki/Meditationes_ sacrae (accessed 21 September 2015).

2 Jeremy M. Schott, Christianity, Empire, and the Making of Religion in Late Antiquity (University of Pennsylvania Press, 2011).

3 Religions are of course all about the 'Sacred.' However, by sacralisation I am more generally referring to the phenomenological process whereby aspects of the secular become sacralised in history. See José Casanova, 'The Secular, Secularizations, and Secularisms' in Craig Calhoun, Mark Juergensmeyer, and Jonathan van Antwerpen, Rethinking Secularism (Oxford University Press, USA, 2011), 65ff. 
lesser, more modest types of deification and its opposite of demonisation that have caused much intricacy and sometimes serious problems in the history of Christianity.

\section{JOHANNES DU PLESSIS: THE VILIFIED SAINT}

In the South African context the interesting case of Johannes du Plessis (1868-1935) is a good example. He, or the public memory of him, has in the relatively short history since his public career in the early twentieth century, been the somewhat unwitting subject of much demonisation/vilification/excommunication on the one hand, only to make a comeback and indeed become a contender for a certain amount of sacralisation in more recent times. ${ }^{4}$

To briefly describe Du Plessis and his relevance in South African theological circles, I mention a few noteworthy aspects of his career. He was a professor at the Stellenbosch Theological Seminary from 1916-1932, teaching both New Testament and Mission Studies. The latter part of his career (1928-1932) was overshadowed by the so-called kerkstryd (church struggle) in the Dutch Reformed Church (DRC), in which Du Plessis found himself accused of heresy due to his moderately positive appraisal of higher criticism. Du Plessis's opponents were either disciples of the neo-Calvinist stream of thought that was flowing forth from Amsterdam under the influence of Abraham Kuyper, or they were schooled in the pre-schism Princeton fundamentalism as brought to South Africa by D.R. and L.P. Snyman and D.G. Malan. ${ }^{5}$ As Murray Coetzee pointed out in his dissertation, it was actually a combination of North American fundamentalism and Amsterdam neo-Calvinism that eventually won the day in Dutch Reformed theology, ${ }^{6}$ and which aided its subsequent twentieth century development as a fortress of isolationist thinking and self-perceived orthodoxy.

Perhaps only indirectly related to the kerkstryd was the fact that Du Plessis was an internationally acclaimed mission theorist and organiser of ecumenical conferences. ${ }^{7}$ He wrote several books and articles, including his 'The missionary situation in South Africa' which was published in 1912 in the first volume of the International Review of Missions. ${ }^{8}$ The well-known late twentieth century South African theologian,

4 The present existence of his statue on the grounds of the theological faculty at Stellenbosch University should serve as substantiation of this claim. In a post - '\#RhodesMustFall' South Africa, the idea that whatever is sacred and revered for some will be vilified by others does not need much elaboration, particularly in relation to statues.

5 Abraham Stefanus Erasmus, Prof. Johannes du Plessis 1868-1935: Baanbreker, Verbreker van die Gereformeerde Geloof (Bloemfontein: UV Teologiese Studies, 2009) 332.

6 Murray Hermanus Coetzee, Die 'Kritiese Stem' teen Apartheidsteologie in die Ned Geref Kerk (1905-1974): 'n Analise van die Bydraes van Ben Marais en Beyers Naudé. (Wellington: BybelMedia, 2010) 170ff.

7 Richard Elphick, The Equality of Believers: Protestant Missionaries and the Racial Politics of South Africa (Charlottesville [Va.]: University of Virginia Press, 2012), 222ff.

8 J. du Plessis, 'The Missionary Situation in South Africa,' International Review of Mission 1(4) 
David Bosch, referred to Du Plessis as the foundation layer of mission scholarship in South Africa. ${ }^{9}$ The successor to Gustav Warneck in Halle, Julius Richter, even dedicated his magnum opus, Geschichte der evangelischen Missionen in Afrika to Du Plessis..$^{10}$ Despite his international scholarly success, Du Plessis had too many enemies among the emerging Afrikaner religious establishment, and the bitter church struggle in South Africa ultimately led to his downfall. He was eventually forced out of his teaching position at the theological seminary, but he went down not without an amount of collateral damage to the $N G$ Kerk (DRC).

The fact is that he was one of the most learned people of his generation, and hence a man of 'knowledge'. He had many supporters, both among rank and file church members, but especially among the so-called missionary enthusiasts. His supporters included a proportion of the theological students at Stellenbosch, and significantly also for this article, missionaries of the Dutch Reformed Church in places such as Mashonaland and Nyasaland. ${ }^{11}$

Due to the much publicised fallout of the kerkstryd, many in South Africa still tend to consider Du Plessis's role mainly in terms of biblical studies. However, as mentioned above, it was mission studies that the bulk of his academic career was devoted to, and it was in this capacity that he sat on various national and international boards and committees. After the disposal, and for all practical purposes excommunication, of this man of knowledge who cherished the optimistic rational intellectualism of nineteenth century academic discourse, there were generally two options open in terms of the popular imagination of interested parties within the Dutch Reformed tradition of subsequent generations in relation to the memory of Du Plessis: (1) further vilification, which steadily became the majority opinion as Afrikaner Christian nationalism gained traction; or (2) as voiced by a vocal minority, some strong apologia for this prophet who was refused a fair hearing in his own land.

Theologically speaking, Du Plessis was an ambiguous character. He rejected biblical inerrancy, particularly the normative views regarding Moses as author of the Pentateuch and the Davidic authorship of some of the Psalms. He basically accepted historical-critical views of the history of Israel, which contradicted the chronological developments presented in the Bible. ${ }^{12} \mathrm{He}$ furthermore held to the so-called kenotic view of Christology, according to which Jesus is understood during his earthly

(October 1, 1912): 573-86.

9 D.J. Bosch, 'Johannes du Plessis as Sendingkundige,' Theologia Evangelica 19(1) (1986b): 6676: 67.

10 Ibid, 68 .

11 Du Plessis wrote letters and received sympathy from W.H. Murray in Nyasaland, for example, and a photo of Du Plessis among mission staff in Mashonaland dated to the year 1926 is entitled 'Where I feel at home.' See for example Erasmus, Prof. Johannes du Plessis 1868-1935, 335, 389.

12 'Die Kerksaak tussen prof. J. du Plessis en die Ned. Geref. Kerk in Suid-Afrika: 'n Woordelikse Verslag van die Verrigtinge, met die Uitspraak, in die Hooggeregshof, Kaapstad, November Desember 1931.' (Nasionale Pers, Beperk, 1931) 5ff. 
sojourn to have temporarily suspended some of his divine attributes, including the ability to be all-knowing. ${ }^{13}$ This idea was necessary for Du Plessis in order to explain how and why Jesus was apparently unaware of some of the textual inconsistencies in the Old Testament that since the nineteenth century was steadily uncovered by higher criticism. The kenotic interpretation as well as the questioning of traditional understandings of biblical authorship and chronology was, however, unacceptable for the ultra-orthodox opponents according to whom Du Plessis was deeply fallen into heresy.

Du Plessis, on the other hand, in his rigorous intellectualism could not help but view fundamentalism and the strict neo-Calvinism of the Kyuperians with a great deal of abhorrence. This did not necessarily make of Du Plessis a modernist/ liberal as his opponents would have wanted to picture him, however. To the contrary, Du Plessis remained a classical evangelical. His most noted work, in addition to those dealing with mission, was his sympathetic biography of the famous revivalist preacher and writer of pietistic evangelical literature, Andrew Murray Jr. ${ }^{14}$

For later generations of students at Stellenbosch University, Du Plessis was mostly known through the visible reminder of the pink marble statue that was posthumously created in his likeness. Over time the statue acquired the disingenuous nickname, Pienk Piet. The emphasis on pienk, Afrikaans for the colour pink, no doubt serves to signify something beyond the purely descriptive purpose of designating the hue of the statue. In Afrikaner popular discourse it might also serve to cast doubt or suspicion on someone's masculinity, and more pertinently in the case of Du Plessis those of left leaning political persuasion. Du Plessis, ironically, as already mentioned, was no liberal and he was no socialist either. He did, however, oppose some of the more extreme abuses committed in the name of segregation such as the so-called Colour Bar Act that was instituted in 1926 with the intention of excluding Africans and Asians from certain forms of skilled work. ${ }^{15}$ These ethnically disloyal tendencies in addition to his 'errant' scriptural views were certainly enough to earn Du Plessis any kind of nationalist Afrikaner insult imaginable.

The pre- and posthumous careers of the colourful Du Plessis and the statue Pienk Piet are stories worth the telling and especially the story of the statue could still benefit from future research. Here it will perhaps suffice to point out that Pienk Piet's positioning vis-à-vis the Stellenbosch Theological Faculty (colloquially known as Die Kweekskool) and its cross-Stellenbosch pilgrimage over the past several decades is a physical expression of this pendulum movement between demonisation and sacralisation relating to the memory of the man himself. The statue, originally commissioned by some of his friends and positioned towards the top of Plein Street in central Stellenbosch, a few years after Du Plessis's death, was vandalised on a

13 See Erasmus, Prof. Johannes du Plessis 1868-1935, 395ff.

14 Johannes du Plessis, Het Leven van Andrew Murray (Zuid Afrikaanse Bijbelvereniging, 1920).

15 Elphick, The Equality of Believers, 206.2012 
number of occasions, a sure indication that at least some reformed Afrikaners had iconoclastic sentiments, at least as far as their heretics were concerned. However, one could also argue that they accorded Du Plessis a level of power by demonstrating this need to physically attack the iconic statue. Why do people vandalise a statue, if not for the at least partly subconscious need of exorcising its spirit? Whatever the case, as the unpopularity of this statue's display in central Stellenbosch illustrates, $\mathrm{Du}$ Plessis remained a divisive character among the mainstream of Afrikanerdom, even after his death.

After its removal from Plein Street, the statue was apparently moved to several different locations around the town. Eventually it was placed in the back garden of the Sasol Art Museum. On a number of occasions the NG Kerk (Dutch Reformed Church) was offered the opportunity to receive back the statue for the Kweekskool, but this offer to posthumously welcome back and reconcile with its formerly outcast professor was typically declined. This impasse remained until a change of heart occurred more recently under an increased ecumenical inclusiveness at the Kweekskool, which happened concurrently with a much more positive reappraisal of Du Plessis's theological contributions. ${ }^{16}$ Since 2006 Pienk Piet has found its home on the Kweekskool grounds, not in the centre of things, but somewhat hidden away in a corner. It nevertheless stands in the front garden, from where it faces the main building, and its temporal inhabitants.

\section{INTELLECTUAL INFLUENCES ON DU PLESSIS'S MISSIONARY THEORY}

The theology and practice of mission work in the Dutch Reformed Church in the early to middle twentieth century, of which Du Plessis was a primary exponent, were strongly influenced by the theories of the above-mentioned pioneer German missiologist, Gustav Warneck, if authoritative sources such as David Bosch and Johann Kinghorn are to be believed. ${ }^{17}$ According to the more recent work done by Richard Elphick, Bosch made too much of the influence of Warneck on Du Plessis, ${ }^{18}$

16 Vincent Brümmer, Vroom of Regsinnig? Teologie in Die NG Kerk. (Wellington: Bybel-Media, 2013).

17 Bosch, 'Johannes du Plessis'; J Kinghorn, 'Die Groei van 'n Teologie - van Sendingbeleid tot Verskeidenheids-Teologie,' in Die NG Kerk en Apartheid. (Johannesburg: Macmillan, 1986).

18 Elphick, The Equality of Believers, 224ff."publisher" 
but as indicated in my note below this criticism is actually based on a misreading of Bosch, probably influenced by Elphick's own interest in portraying Du Plessis as much as possible belonging to Anglo-American evangelical circles. ${ }^{19}$ For his part, Kinghorn tempers his own point regarding Warneck's influence on Du Plessis by cautioning that this should not be over-estimated, and that Warneck's influence was hardly unique to the Dutch Reformed Church. ${ }^{20}$ 'All other churches in South Africa, and especially the Lutherans, were likewise infiltrated by this mission theory' [my transl.]. ${ }^{21}$

Nevertheless, the influential perspective championed by Bosch has become virtually sacrosanct in a number of subsequent writings on what has been termed Afrikaner Civil Religion. ${ }^{22}$ According to this view, Warneck's mission theory, including what would later be regarded as its controversial nation-centred anthropology, did manage to find its way into mainstream Afrikaner ideology. The extent to which Warneck's theories were endorsed and appropriated by Du Plessis, and by extension in the work of his admiring successor G.B.A. Gerdener, who was one of the most significant early apartheid theologians and the son of a German Rhenish missionary himself, evidently remains a subject of some debate, the basics

19 I doubt that this criticism of Bosch holds much water. There is no doubt that Du Plessis held Warneck in high esteem, because he said so himself. Already in 1910 Du Plessis mentioned his interest in an English translation of Warneck's Evangelische Missionslehre as he considered this text to be one of a kind (See A. S. Erasmus, Die bediening van Johannes du Plessis, 1868-1935 in die Ned. Geref. Kerk met besondere verwysing na sy teologiese denk: 'n Kerkhistoriese studie (Proefskrif DTh Universiteit van Stellenbosch, 1986, 165).

Elphick's reading of Bosch seems to be based on a misinterpretation of what is actually going on in the text. Elphick, in his own preoccupation to point out the epistemological divergences between 19th century German and Anglo-American approaches to mission, wishes to place Du Plessis quite firmly in the Anglo-American camp. Bosch on the other hand had no such concern. From his point of view, there was no dichotomy between Warneck and the Venn-Anderson schema of the 'three selves'. Du Plessis generally followed all of these 19th century theorists, but perhaps Warneck more than the others for the simple reason that the German had more thickly worked out theologically the implications of his theory than the Anglo-Americans had done. Elphick then rather ironically neglects to mention the fact that Bosch also ultimately places Du Plessis implicitly yet firmly in the developing Anglo-American camp in its 20th century formation by pointing out Du Plessis's rather uncritical appraisal of W.E. Hocking's Re-Thinking Missions with its optimistic perspective on the fruits of modernity on the one hand, and on the other hand his absolute non-appreciation for the work of Karl Barth, as well as Du Plessis's apparent ignorance of the significant missiological reinterpretation of Barthian theology by another German, Karl Hartenstein, who reintroduced the concept of Missio Dei into 20th century theological discussion (See Bosch 1986, 69ff).

20 J Kinghorn, 'Die Groei van 'n Teologie,' 68ff.

21 Ibid, 69.

22 D.J. Bosch, 'Afrikaner Civil Religion and the Current South African Crisis,' The Princeton Seminary Bulletin 7(1) (1986a): 1-14null.; Dirkie Smit has thoroughly dissected the term civil religion in South Africa, and has pointed out a number of inherent weaknesses in relation to its use - Dirk J. Smit, 'Civil Religion - in South Africa?' in Essays in Public Theology: Collected Essays 1 (Sun Press, 2007) 101-23. 
of which shall now be described in further detail, at least in as far as it relates to Du Plessis.

Although he cited the work of Warneck as a primary source for mission theory in the foreword and bibliography of his important book on the subject, Wie sal gaan? [Who will go?] and generally accepted the philosophy of Volkschristianiserung as one goal of mission, Du Plessis does not refer all that much to Warneck within the body of the text. Elphick correctly points out in support of Du Plessis's biographer Gerdener $^{23}$ that Du Plessis was far more conversant in literature emanating from the English-speaking world than with German and even Dutch sources. Quite likely his own ideas regarding an indigenous church principle leaned just as heavily on the 'three selves' (self-govern, self-support, self-propagate) of indigenous church planting as propagated by the nineteenth century Anglican strategist of the Church Missionary Society, Henry Venn, and Rufus Anderson of the American Board of Commissioners for Foreign Missions (more on this below). Elphick quotes Du Plessis as stating that 'the ultimate goal (eindoel) of missions was "the founding, among non-Christian peoples, of a Church that does not always need to be fed and supported by the mother church, but that learns to maintain, govern, and enlarge itself'. ${ }^{24}$ This, Elphick, points out, 'was the classical formulation of English-speaking missions, the "three-selves" propounded by... Venn... and...Anderson' ${ }^{25}$

The otherwise astute Kinghorn seems to miss this point in his discussion of Du Plessis's Wie sal gaan? He states that in Warneck's missiology the goal of mission is the founding of an independent 'volkskerk'. Then he quotes Du Plessis with the aim of illustrating the latter's apparent agreement with Warneck as follows: (see note). ${ }^{26}$ Inboorlingkerk is however not synonymous with volkskerk. The former more specifically refers to native church, even indigenous church to use currently more appropriate language. So this quotation might be translated into English as follows: 'The native/indigenous church must be rooted in the people's life world... and it must be reckoned as flowing forth from the people's life world and not as an imported and foreign institution.'

The reader will notice that by translating volkslewe as people's life world I am perhaps deliberately deemphasising any overt ideological connotation to the term volk as in agreement with Elphick and others I do not have the impression that Du Plessis was especially enthralled by any such interpretation himself. Do I thereby go along with Elphick, and allow Du Plessis off the hook of romantic nationalism entirely? No, because even if Elphick criticises Bosch for maintaining

23 Gustav Bernhard August Gerdener and Johannes du Plessis, Die Boodskap van 'n man (ChristenStudentevereniging, 1943).

24 Elphick, The Equality of Believers, 224.

25 Ibid.

26 'Die inboorlingkerk moet in die volkslewe gewortel wees...en beskou word as uitvloeisel van die volkslewe en nie as 'n ingevoerde en vreemde instelling nie.' Kinghorn, 'Die Groei van 'n Teologie - van Sendingbeleid tot Verskeidenheids-Teologie,' 68. 
that Du Plessis's exegesis of Mt. 28 regarding the panta ta ethne was basically the same as Warneck's, i.e. the Christianisation of distinct nations/ethnic groups rather than the whole of humanity as such, there is no escaping the fact that Du Plessis also wrote, as clearly highlighted by Bosch, in Wie sal gaan? that missionary work should strengthen the 'volksgees' rather than destroying it, that 'mission should not denationalise an individual or a society, or that the bonds which protect an ethnic unit should not be weakened or become unbound' [my transl.]. ${ }^{27}$

That these types of sentiments were not absolute or central in Du Plessis's thinking and were even implicitly contradicted by much of the thrust of his argumentation elsewhere, is however apparent for example where Elphick quotes him as follows: 'While the Savior speaks of all the peoples, viewed as separate nations, he further says that they must be baptised and taught, not as separate peoples (auta) but as separate persons (autous).' ${ }^{28}$ Elphick furthermore makes the point that no more than 'two of the thirty chapters of Wie sal gaan? drew on the German school to address the issue of "die volkere", 29

\section{DU PLESSIS'S AMBIGUOUS HISTORICAL ROLE IN CONTRAST TO DISCOURSES OF SACRALISATION/ VILIFICATION}

The above will suffice to suggest that Du Plessis was perhaps no rigid ideologue regarding matters of race and ethnicity, but it should also caution against the somewhat overly enthusiastic recent tendency to sanitise his legacy. This sanitisation is partly driven by the fact that Du Plessis's progressive stance towards higher criticism has more recently, even in the mainstream Afrikaner Reformed tradition, become thoroughly embedded and celebrated in what might be termed the dominant discourse, in the sense that the results of higher criticism are now, as opposed to in the early twentieth century, generally considered to be 'true'. Therefore a certain sacralisation of $\mathrm{Du}$ Plessis as one of the few proverbial good guys in Afrikaner history is imminently attractive.

One problem with this perspective is that Du Plessis was also apparently quite convinced that races were inherently distinct as the following quotation illustrates:

The white and black races both have their own volks ideals, which have roots in their different pasts. There is within each volk an inborn tendency to maintain the type to which it belongs and to protect itself against deterioration. It was perhaps the right instinct that possessed the Voortrekkers to countenance no mixing of the blood with the natives. With that they not only kept their race pure, but also carried away the respect of the natives [my transl.]. ${ }^{30}$

27 Bosch, 'Johannes du Plessis as Sendingkundige,' 73.

28 Elphick, The Equality of Believers, 225.

29 Ibid, 369 n. 17.

30 Johannes du Plessis, Wie sal gaan?: Of die sending in teorie en praktyk (Die S.A. Bybelvereniging, 1932) 195-196. 
In addition to such ideas, Du Plessis firmly believed that contemporary black South Africans were politically and socially minderjarig (transl. 'underage'). ${ }^{31}$

Therefore, although he was no biological racist in a social-Darwinian sense, $\mathrm{Du}$ Plessis evidently did hold a hierarchical view of races. This hierarchy was based on a firmly embedded aspect of Du Plessis's own contextual archive of 'knowledge' with its optimistic, even triumphalist view of European Christian civilisation. Societies around the world were then ranked according to the ways they were perceived to approximate or differ from the Western norm. In accordance with the optimism of this view even the so-called 'lower races' could however progress and uplift themselves to the level of the Christian European, but naturally this would take time and much 'guidance'. This was still a dominant discourse in the early twentieth century, especially among the colonial outposts of European societies such as white South Africa, where older ideas tended to be more entrenched with an extended shelf life when compared to the shifting winds on the European continent itself.

As had happened with the local adaptations of other ideas imported from overseas, such as the Neo-Calvinism of the Dutch theologian Abraham Kuyper, Warneck's missiology was similarly invoked in the service of the twentieth century development of ideologies of separateness. A focus on the preservation of ethnicity was a point of view that could be employed in the interest of ideological separateness. Elphick mentions the case of a Dutch-born minister Cornelis Spoelstra, who in 1900 made liberal use of Warneck in a treatise on Boer attitudes to mission:

Paraphrasing and embroidering Gustav Warneck...Spoelstra insisted that missionaries take account of the "languages, climate, character of each people [volk], political and social relations, the level of civilization, morals, and religious ideas". There could be "no question of levelling the individuality of any volk...Each volk has its necessary location and the task it has received from God". The Boers understood the folly of ignoring the differences and hierarchies among nations; the English did not. ${ }^{32}$

Apartheid implicitly promoted an understanding of the sanctity of separateness, which could only be maintained as long as the ideal of fixed ethnicity would become not only a legal issue but a moral principle to boot. Du Plessis himself articulated this 'moral' side of the equation when he wrote about racially mixed marriages in Wie sal gaan? In principle he claimed not to have a problem with it. 'Nobody would begrudge a marriage between an Afrikaner and a German or a Scot (except maybe for sentimental reasons). However, when a member of a higher race marries a member of a lower race, then the experience teaches that in many cases the children inherit not the virtues, but the ill-virtues of both races' [my transl.]. ${ }^{33}$ To a great extent apartheid ideologues of a later generation were very much successful in convincing

31 Ibid, 95.

32 Elphick, The Equality of Believers, 170-171.

33 Du Plessis, Wie sal gaan? 106 
for a substantial period of time the vast majority of white South Africans of this 'moral' imperative.

To return to the so-called influence of overseas intellectual streams on Afrikaner thinking, one could suggest that they were in a sense disembodied or decontextualised. To hold either Kuyper or Warneck responsible for what developed in South Africa would be to misinterpret their roles within the emerging discourse of apartheid in the twentieth century. Their names were added in to fill out a picture. To make a totalitarian system seem more intellectually coherent than it actually was.

In spite of the compromised figure I sketched of Du Plessis above, it is also necessary to further emphasise, as I have alluded to above regarding his opposition to the Colour Bar Act, that he was astute enough to realise that the economic segregationist policies that preceded apartheid ideology, still in its embryonic phase during his public career, was completely untenable. Du Plessis wrote that it was an 'onverstandige beleid' - (unintelligent policy) to attempt to exclude the black population from full participation in the South African economic system. ${ }^{34}$ True to his sitz im leben as a white South African man in the early twentieth century, Du Plessis portrays an extremely patronising and paternalistic attitude towards the indigenous population and their concerns. He was, however, clearly convinced of their potential to rise up to the level of whites under the influence of Christian civilisation. Writing about how unreasonable and unchristian it would be to deny Christianised black South Africans the fruition of their ambitions acquired as a result of exposure to the gospel, Du Plessis asks: 'What kind of mother shows her child a beautiful peach, only to throw it away or hide it so that the child cannot see it anymore, and never may eat it? If we show the native the great possibilities of the Christian civilisation, then we must also help him to transform these possibilities into realities' [my transl.]. ${ }^{35}$

To return to the theme of possible German theological influences, there is something interesting about Warneck and the missiology inspired by his legacy, however indirectly it might have featured in South Africa, which points to a great irony of history. One underlying theme in Elphick's book, The Equality of Believers, is the idea that the legacy of British missions to South Africa inculcated values of equality and rights, whereas the German legacy, especially in the way it became rooted in Afrikaner mission policy after the exit of Du Plessis, achieved only to be employed to legitimise apartheid. One could perhaps take this issue at face value, for the sake of constructing an alternative history, for example, to argue that if the British anti-culturist mission policies were unequivocally successful, if it had no competition from other discourses, in other words, then equal rights and democracy might indeed have come far sooner to South African shores. On the other hand, indigenous systems of knowledge might have suffered even more from the colonial onslaught than they actually did.

$34 \quad$ Ibid, 107.

35 Ibid, 108. 
A peculiar aspect of Warneck's theology and its South African adaptations, and which of course makes it of relevance for discussions on the topic of 'indigenous knowledge systems', is the fact that it had as one of its points of departure the principle or idea that there should be as little as possible interruption to the cultures of groups which were being missionised. To reiterate what has been alluded to before, it cherished the indigenous church principle. The integrity of local languages and customs should be preserved rather than destroyed by missionary activity. Far from being an oppressive insistence on only one way of being, this might be seen as an enlightened, one could even say culturally relativist perspective; somewhat reminiscent of the radical scepticism so in vogue with some postmodern writers, including Michel Foucault (see below). Was it not simply an ironic twist of history that these ideas found themselves well-suited to the kinds of ideals that apartheid ideologues held dear?

To distil some points from the above that I consider particularly significant, I mention the following: knowledge is power in the modern West. Therefore is it a Western temptation to either sacralise or demonise those understood to be highly knowledgeable? If so, then let me make the further point, which I shall further elaborate below, that this is hardly different from indigenous systems where rain specialists and practitioners or indigenous medicine might be either revered as living gods or despised as 'witches'. In these contexts knowledge is/was also power.

A second, unrelated issue is that the sacralisation of a salvific ideology that promised an entrenchment of power for white South Africans against all odds and rationality was part of what kept apartheid going for so long. Du Plessis was not responsible for this ideology, which really developed only after he had left the scene. However, although he had an ambiguous hand in debates surrounding race and segregation, he did significantly contribute to the theme of a 'moral' imperative regarding these matters.

\section{THE MISSION FIELD AND ITS APPROXIMATIONS OF LIMINALITY}

Indigenous conceptions of power are similarly related to knowledge, but in the case referred to here, particularly the type of knowledge that can control the environment. Western rationalist knowledge on the other hand has until fairly recently claimed an astounding degree of ignorance in terms of both environmental impact as well as the human ability to make a difference. I therefore maintain that a meeting on common ground between various traditions might not be a meaningless exercise. In fact depending on how we read our history, we might actually learn something of value there. In this vein, theologian Johan Cilliers describes the system of colonialism according to Foucault's notion of heterotopia. ${ }^{36}$ Heterotopias are described as

36 Johan Cilliers, 'Power, Space, and Knowledge: Theological-Aesthetical Perspectives on Michel Foucault's Contribution to Post-Colonial Theory,' Scriptura 112(1) (n.d.): 1-13: 9. 
'places which bear an unconventional relationship to other places by neutralising, suspending, or reversing the relationships through which we can normally point at them, reflect on them, or conceive them' ${ }^{37}$

If the colonial encounter could be imagined in terms of such geographical and conceptual spaces of 'otherness', then I could point out that the colonial mission field was even more directly heterotopic. The mission field placed single-minded colonial-era Westerners in close proximity with indigenous peoples who obviously had their own expectations including the odd innovative plan regarding how to exploit the evangelistic context for personal or communal gain. This was a sort of situation fraught with the potential for miscommunication, misunderstanding, and even comical role reversals. Some aspects of this context were brilliantly, if fictionally, captured in Barbara Kingsolver's Poisonwood Bible. ${ }^{38}$ Whether one is sympathetic to Kingsolver's missionary characterisations, or not, informed scholars tend to agree that the mission field was an interesting place where things were not always what they seemed. ${ }^{39}$

The mission theory championed by Du Plessis implicitly created or rather adapted itself to the kind of situation where Dutch Reformed missionaries could not simply dismiss indigenous 'superstition' as irrelevant. No, they had to find ways of responding to such concerns in correspondence to the logic of the indigenous context.

There are Afrikaner missionary accounts that relate how the Dutch Reformed missionary enterprise in early twentieth century Nyasaland were effectively drawn into rain praying competitions with indigenous rain specialists. ${ }^{40}$ These missionaries naturally believed that their insistence on the exclusive power of the Christian God to provide rain was an issue of the positing of absolute truth over the falsehoods of indigenous peoples. They had no doubt that they had truth on their side. What is however ironic, if we consider the mission field as a kind of liminal or heterotopic space, is the very fact that they entered into a sort of bargain with indigenous peoples by praying for rain as response to expectations emerging out of indigenous cosmological theory regarding explanation, prediction, and control. I am positing the question whether there might have been reversals of roles, where the missionary context found itself unexpectedly led by the indigenous context, for example? By instituting bidure (prayer meetings) for rain, often upon the request of the indigenous population, and by making much publicity of instances where an indigenous rain

37 Ibid, 6.

38 Barbara Kingsover, The Poisonwood Bible (HarperCollins, 1998).

39 See Ingie Hovland, Mission Station Christianity: Norwegian Missionaries in Colonial Natal and Zululand, Southern Africa 1850-1890 (BRILL, 2013).

40 Andrew Charles Murray, Ons Nyasa-akker: Geskiedenis van die Nyasa Sending van die Nederd. Geref. Kerk in Suid-Afrika (Pro Ecclesia, 1931) 188; J. A. Retief, Ontdekkings in Midde-Afrika (C.S.V. Boekhandel, 1961), 145. 
specialist apparently converted to Christianity, ${ }^{41}$ they were perhaps not merely doing the obvious, i.e. trumpeting the dominance of their own belief system, but actually acknowledging the religious legitimacy of the environmental concerns within the indigenous system. In short there are two discourses at play here, the one dominantly triumphalist; the other more subtle, incidental even, but with the potential to be subversive.

The subversive potential of liminal spaces is well documented. The statue of Pienk Piet described above is also a contested space. In its case the subversive discourse inherent in the statue eventually proved victorious. The bold inscription in the wall behind its present position tells the full story: 'God verdedig die Reg' (God defends the right/righteous) it proclaims. No doubt die regsinniges (neo-orthodox opponents) of old, whose supporters had made it an occasional pastime to desecrate the statue are spinning in their graves! The story of Johannes du Plessis is set to remain a contested and divisive one.

\section{CONTEMPORARY HYBRID MANIFESTATIONS OF INDIGENOUS KNOWLEDGE IN SOUTHERN AFRICA}

One might debate the extent to which the mission field could really be such a liminal space or a heterotopia, but the fact remains that Christianity in its more thoroughgoing indigenous incarnations in twentieth century southern Africa, such as seen in the Zion Christian Church (ZCC), for example, shows a strong propensity for linking rain forecasts to the charismatic praying ability of a powerful church leader who is understood to have access to the spirit world. A related question to ask would be whether indigenous knowledge has in fact transcended the 'indigenous' to infiltrate that which sought to invade it, the colonising white culture? The former white Zimbabwean farmer turned evangelist of the heavily attended Mighty Men Conferences in contemporary KwaZulu-Natal, South Africa, Angus Buchan, was reported to have prayed for rain with apparent success in Bloemfontein. One of the commentators on a blog, which described the event in question, states the following: 'Well done Angus bring the heavenly rain thank you aba Farther Jesus our lord. ${ }^{42}$

The interesting thing here is of course that the white Angus himself is credited with bringing the rains. This is not all that different in other words from the spirituality prevalent in some forms of African Indigenous Christianity, where the ZCC's Bishop Lekganyane, for example, is called by some of his church members 'the man with the keys to the rain'. ${ }^{43}$

41 Retief, Ontdekkings, 145.

42 Lyzette Hoffman, 'Buchan in Bloem to Pray for Rain, Korkie,' Gatewaynews.co.za, January 31, 2014, http://gatewaynews.co.za/buchan-in-bloemfontein-to-pray-for-rain-korkie/.

43 Retief Müller, African Pilgrimage: Ritual Travel in South Africa's Christianity of Zion (Farnham: Ashgate, 2011) 164. 
I leave the question regarding possible cross-cultural diffusion in respect to Buchan and the Mighty Men unanswered for now, but indigenous forms of Christianity have in the past crossed boundaries in unexpected ways. ${ }^{44}$ It is perhaps appropriate that the ambiguous character of Johannes du Plessis was particularly influential in originally introducing the indigenous church concept into the DRC missionary context. Challenging and problematic as the memory of the man is to deal with, this aspect of his legacy might further serve to stimulate debate among religious and theological scholars in future.

\section{CONCLUSION}

Although I do not wish to institute such a debate at this point, I do think that when it occurs it might do well to proceed along interdisciplinary lines, because not only theologians struggle with the intercultural meeting of worlds. Similar concerns are revealed from different perspectives, for example in a prominent book by the title, Magic and Modernity: Interfaces of Revelation and Concealment, written by a number of pre-eminent cultural anthropologists, this volume problematises the traditional binary of modernity and magic (indigenous knowledge systems to use the language I employ in this article). As co-editor, Peter Pels states in the introduction: 'Both the modern rationalist and the magically backward subject constituted by [most theories on these subjects] are modernist myths that need to be scrutinised by empirical research. ${ }^{45}$ Pels and other authors in this book show, much as I have tried to do throughout this article, that what might from one point of view be considered rational and modern is really 'haunted' by the themes of that which were supposed to be exorcised (or disenchanted to use Max Weber's term) by Western civilisational processes. I have focused on the word 'sacralisation' because of power connotations implied by it to describe this haunting of supposedly rational institutions, spaces, and people, which of course includes Protestant Christianity as a supposedly rationalised religion, to again allude to Weber.

Co-editor of Magic and Modernity, Birgit Meyer has also in an earlier publication described a related illusionary dividing wall between the sacred and the demonic when she argued in her famous study of Ghanaian Pentecostals by the title Translating the Devil that one primary purpose of the exorcising activities occurring within these churches is really, contrary to expectations on the surface, the outcome of a deeper need to remain in conversation with older, supposedly supplanted, spiritual realities. ${ }^{46}$ Former gods became demonised under the Pentecostal advance.

44 See Andrew F. Walls, The Cross-Cultural Process in Christian History: Studies in the Transmission and Appropriation of Faith, First Edition (Orbis Books, 2002).

45 Peter Pels, 'Introduction,' in Magic and Modernity: Interfaces of Revelation and Concealment (Stanford: Stanford University Press, 2003) 1-38: 31.

46 Birgit Meyer, Translating the Devil: Religion and Modernity among the Ewe in Ghana (Trenton, NJ: Africa World Press, 1999). 
And so an exorcism is really none other than the attempt to maintain continued contact with these entities, a contact which is successful in spite of the fact that the style of address is, under the guise of Pentecostalism, no longer reverential, but in fact rather abusive.

I consider these types of anthropological studies important for continuing the interdisciplinary conversation regarding both the paradoxical and entangled natures of indigenous knowledge systems within the context of the postcolonial nationstate. In a sense they normalise or at least demythologise 'otherness', which is a perspective that I think could be useful for historiographers of the South African religious landscape. If well appropriated, such a perspective might serve to inhibit unhelpful sacralising/demonising tendencies, at least within the purview of academia.

I began this article by relating some of the paradoxes related to the life and memory of Johannes du Plessis, the Afrikaner scholar who was principally responsible for propagating the idea of the 'indigenous church principle' in early twentieth century South Africa. On the one hand, Du Plessis could be described as enlightened, even progressive for his socio-historical context, enough so to be anathematised by his primary reference group. On the other hand, he held racial views that, when interrogated now, are hard to stomach for the contemporary ecumenical theological discourse in post-apartheid South Africa. This is a discourse that from some quarters might have been overly eager to present Du Plessis as an unblemished historical ray of light, a signpost for better things to come.

I then mentioned one of the inadvertent accomplishments of the indigenous church principle, which is particularly exemplified in some of its more radical, but highly popular offshoots such as the indigenous African Christianity found in Zionist churches. This concerns the preservation and cross-diffusion of indigenous systems of knowledge. Of course, rain praying is also rooted in biblical tradition, so this is really a case of hybridity. ${ }^{47}$ Might an intriguing case of a type of unintended crossdiffusion and hybridity be also found in the rain-praying context of the predominantly white and Afrikaans Mighty Men Conferences?

Concerning these South African examples then, one might point within the Christian theological and popular religious discourses to various pendulum movements between sacralisation and vilification, where the one could turn into the other with every turn of history, often without participants really being consciously aware of the ironies and implicit paradoxes inherent in the processes they engage in.

The real issue exposed in all of this is, of course, the question of 'knowledge' and its contested nature. In a sense it is an easy task to puncture holes into assertions of knowledge when the theme is considered historically, in respect to the currently rather unpopular colonial discourse. However, in our contemporary intellectual

47 See Retief Müller, 'Understanding Christianity in the history of African religion: An engagement with theological and anthropological perspectives in the pursuit of interdisciplinary dialogue.' Verbum et Ecclesia [online] 2014, vol. 35(2). 
climate the theme of 'indigenous systems of knowledge' finds itself perched on an increasingly elevated pedestal. Will this kind of 'knowledge' be open to rigorous intellectual scrutiny, or will it too fall prey to the unhelpful binary of sacralisation/ vilification?

\section{LIST OF REFERENCES}

Bacon, Francis. 'Meditationes Sacrae.' https://en.wikisource.org/wiki/Meditationes_sacrae. Wikisource (accessed 21 September 2015).

Bosch, David J. 'Afrikaner Civil Religion and the Current South African Crisis.' The Princeton Seminary Bulletin 7(1) (1986): 1-14null.

Bosch, David J. 'Johannes du Plessis as Sendingkundige.' Theologia Evangelica 19(1) (1986): 66-76.

Brümmer, Vincent. Vroom of Regsinnig? Teologie in Die NG Kerk. Wellington: Bybel-Media, 2013.

Casanova, José. 'The Secular, Secularizations, and Secularisms.' Calhoun, Craig, Mark Juergensmeyer, and Jonathan van Antwerpen (eds.), Rethinking Secularism. Oxford University Press, USA, 2011.

Cilliers, Johan. 'Power, Space, and Knowledge: Theological-Aesthetical Perspectives on Michel Foucault's Contribution to Post-Colonial Theory.' Scriptura 112(1) (n.d.): 1-13.

Coetzee, Murray Hermanus. Die 'Kritiese Stem'teen Apartheidsteologie in die Ned Geref Kerk (1905-1974): 'n Analise van die Bydraes van Ben Marais en Beyers Naudé. Wellington: Bybel-Media, 2010.

'Die Kerksaak tussen prof. J. du Plessis en die Ned. Geref. Kerk in Suid-Afrika: 'n Woordelikse Verslag van die Verrigtinge, met die Uitspraak, in die Hooggeregshof, Kaapstad, November - Desember 1931.' Nasionale Pers, Beperk, 1931.

Du Plessis, J. 'The Missionary Situation in South Africa.' International Review of Mission 1(4) (October 1, 1912): 573-86. doi:10.1111/j.1758-6631.1912.tb00691.x.

Du Plessis, Johannes. Het Leven Van Andrew Murray. Zuid Afrikaanse Bijbelvereniging, 1920.

Du Plessis, Johannes. Wie sal gaan?: Of die sending in teorie en praktyk. Die S.A. Bybelvereniging, 1932.

Elphick, Richard. The Equality of Believers: Protestant Missionaries and the Racial Politics of South Africa. Charlottesville [Va.]: University of Virginia Press, 2012.

Erasmus, Abraham Stefanus. Die bediening van Johannes du Plessis, 1868-1935 in die Ned. Geref. Kerk met besondere verwysing na sy teologiese denke: 'n Kerkhistoriese studie. Proefskrif DTh Universiteit van Stellenbosch, 1986.

Erasmus, Abaham Stephanus. Prof. Johannes du Plessis 1868-1935: Baanbreker, Verbreker van die Gereformeerde Geloof. Bloemfontein: UV Teologiese Studies, 2009.

Gerdener, Gustav Bernhard August, and Johannes du Plessis. Die Boodskap van 'n man. ChristenStudentevereniging, 1943.

Hoffman, Lyzette. 'Buchan in Bloem to Pray for Rain, Korkie.' Gatewaynews.co.za, January 31, 2014. http://gatewaynews.co.za/buchan-in-bloemfontein-to-pray-for-rain-korkie/. 
Hovland, Ingie. Mission Station Christianity: Norwegian Missionaries in Colonial Natal and Zululand, Southern Africa 1850-1890. BRILL, 2013.

Kinghorn, J. 'Die Groei van 'n Teologie - van Sendingbeleid tot Verskeidenheids-Teologie.' In Die NG Kerk en Apartheid., 86-116. Johannesburg: Macmillan, 1986.

Kingsolver, Barbara. The Poisonwood Bible. HarperCollins, 1998.

Meyer, Birgit. Translating the Devil: Religion and Modernity among the Ewe in Ghana. Trenton, NJ: Africa World Press, 1999.

Müller, Retief. African Pilgrimage: Ritual Travel in South Africa's Christianity of Zion. Farnham: Ashgate, 2011.

Müller, Retief. 'Understanding Christianity in the history of African Religion: An engagement with theological and anthropological perspectives in the pursuit of interdisciplinary dialogue: Original Research.' Verbum et Ecclesia [online] 2014, 35(2): 1-9.

Murray, Andrew Charles. Ons Nyasa-akker: Geskiedenis van die Nyasa Sending van die Nederd. Geref. Kerk in Suid-Afrika. Pro Ecclesia, 1931.

Pels, Peter. 'Introduction.' In Magic and Modernity: Interfaces of Revelation and Concealment, 1-38. Stanford: Stanford University Press, 2003.

Retief, J. A. Ontdekkings in Midde-Afrika. C.S.V. Boekhandel, 1961.

Schott, Jeremy M. Christianity, Empire, and the Making of Religion in Late Antiquity. University of Pennsylvania Press, 2011.

Smit, Dirk J. 'Civil Religion - in South Africa?' In Essays in Public Theology: Collected Essays 1, 101-23. Sun Press, 2007.

Walls, Andrew F. The Cross-Cultural Process in Christian History: Studies in the Transmission and Appropriation of Faith. First Edition. Orbis Books, 2002. 